\title{
India in The Pakistan Times, September 1950-February 1951
}

\begin{abstract}
This article offers a glimpse of the representation of India in The Pakistan Times in 1950-51, in the last months of the first phase of its editorship by Faiz Ahmed Faiz. It contextualizes this reflection in a period of relative lull, marked by pacts on minorities and trade, within the postPartition upheaval. Focusing especially on editorials, commentaries and cartoons, it highlights the formation of views of the neighbour from the news that was being generated. The stress is on firstly, a variety of themes included - not just the "unfinished business of Partition", secondly, a responsible review of these themes - not just a narrow-minded nationalist reading, and thirdly, an involved - if not intertwined - interpretation of both countries' socio-economic relations, while not underplaying the differences of their regimes. Further, the article goes beyond an intergovernmental framework, as The Pakistan Times went beyond it and presents a slice of the possibilities then existing, of a progressive politics on questions of class, community and capital. In early independent Pakistan, this was personified by Faiz and this article, while not on him nor on an extensive Saidian reflection of the "other", tries to trace his imprint in the representation of India in the newspaper he edited and seeks to contribute to our understanding of India as constructed through Pakistani eyes.
\end{abstract}

Keywords: The Pakistan Times, India, Faiz Ahmed Faiz, 1950-51

Word count: 13600 approx. (including endnotes) 


\section{Introduction}

Historians have long recognized the reality of newspapers as a primary source to reconstruct the public sphere. ${ }^{1}$ This is especially true for those who struggle along the archival grain, ${ }^{2}$ while researching Colonialism in South Asia. ${ }^{3}$ In the last 25 years, from participation of Indian press in the freedom struggle to observing the role of media in the British Empire, ${ }^{4}$ many explorations in such historical communication have been made. ${ }^{5}$ In the historiography of the Partition of British India, newspapers have richly contributed in restoring a human dimension to high politics by helping retrace the traumatic experiences of migrants, riot-victims and refugees, in particular women among them. ${ }^{6}$ Afterwards, people's everyday expectations from their nation-states have been best extracted from newspapers. ${ }^{7}$ Indeed, the demand for Pakistan by the All-India Muslim League in 1940s saw the emergence of Dawn as "the main avenue" for the advocacy of this demand ${ }^{8}$ in effect, a "national newspaper" before the creation of the nation. ${ }^{9}$ Located between the late-colonial state, its ideology and institutions, on the one hand and the nationalizing society, its intelligentsia and parties, on the other, newspapers not only helped frame public opinion but also helped forge or fray beliefs, identities, reform and resistance.

However, once this rite of passage was gone through, producing its "partisan reporting", ${ }^{10}$ not more than routine reflection has been offered on representing the neighbour in India's and Pakistan's major newspapers, unlike other examples of identity formation, depiction and thus

alterity through a theoretical discourse on media and identity. ${ }^{11}$ Richer research exists on internal issues like press censorship and the politics of Indian-language press, ${ }^{12}$ and censorship and leftwing press in Pakistan. ${ }^{13}$ In the case of contemporary India, Muslims are made to stand-in for 
Pakistan and this framing has been more regularly studied. ${ }^{14}$ In the case of contemporary Pakistan, more work exists on "language and gender stereotypes" and "representation of cultural diversity". ${ }^{15}$ It is left to media watchdogs like The Hoot to analyze how India's The Hindu and Pakistan's Dawn cover each other's countries. Unsurprisingly, given their “divergent paths", the analysis "shows the latter giving India more space and more diverse coverage". ${ }^{16}$ The unmistakable conclusion that "Indians are not very keen to know about Pakistan unless something bad happens..." was reiterated in the 2019 Pulwama-Balakot episode. ${ }^{17}$

In employing newspaper reportage to write history(s) of post-colonial Indian subcontinent, the periods that stand out are those overtly associated with ruptures, for instance 1947-48, 1970-71 and 1975-77. ${ }^{18}$ This article instead is interested at a passing phase of agreement, September 1950-February 1951, and looks at a sliver of representation of India in Pakistan then. To do so, it takes up a gamut of issues reported and commented upon rather than treating an array of identity politics reflected and constructed with. It uses as its historical prism the comparatively overlooked progressive "flag-bearer for the Muslim League", The Pakistan Times,${ }^{19}$ which "in its first editorial described its creed as 'a Muslim Leaguer with Leftist Leanings'" ${ }^{20}$ A pillar of the "print culture and left-wing radicalism in Lahore", as Irfan Waheed Usmani has recently shown, "the newspaper played a responsible role [with] a progressive tone", ${ }^{21}$ while not renouncing those partisan times. It was founded in February 1947 in Lahore by Mian Iftikharuddin (190862), the Oxford educated Punjab politician, who had been with the Indian National Congress (1936-45) before joining the Muslim League. ${ }^{22}$ While Dawn moved from New Delhi to Karachi in 1947, The Pakistan Times was one of "only four major Muslim-owned newspapers" in the part of the region that became Pakistan. ${ }^{23}$ The leading critical English daily by 1950, it became a 
"major thorn in the government's side", ${ }^{24}$ through the ensuing decade and would incur the wrath of General Ayub Khan and be folded in April 1959. ${ }^{25}$

If it was owned by a progressive, then it was edited by another(s), ${ }^{26}$ during the time under focus in the article: Faiz Ahmed Faiz (1911-1984). Variously called "the 'most brilliant' intellectual in Pakistan", ${ }^{27}$ and "Pakistan's unofficial poet laureate", ${ }^{28}$ he would be awarded the Lenin Peace Prize in 1962. In the corpus of writings on him, ${ }^{29}$ comparatively less material exists on "Faiz, the editor" ${ }^{30}$ If, as has been said, "whatever Faiz expressed in his poems, he also wrote in his paper", ${ }^{31}$ then it should be worth our while to see how the editorials of his daily represented India especially as other entry-points like "left-wing parties, writers and press", "radical print culture and professionalization of journalism" and "censorship, takeover and literary resistance" have been employed to analyze the content as well as the context of the Progressive Papers Limited and The Pakistan Times. ${ }^{32}$ This, at a time, when the debate in Punjab's countryside was moving "from displacement to development", ${ }^{33}$ and, the flow of minorities in Bengal was stemmed by the Nehru-Liaquat Delhi Pact of April 1950. ${ }^{34}$ A new dynamic could be expected in IndiaPakistan relations, while not diminishing the dispute on Kashmir (or, the Canal Water) ${ }^{35}$ which remained sui generis and was thus reported/editorialized in the pages of The Pakistan Times, representing state policy and/or popular sentiment. [Cartoon: "KASHMIR: Function and Functionary"]

As this article attempts to show, however, there was more to the reflection on India, covering themes like (a) internal politics of the Congress and the external socialist-communist opposition to it, (b) importance of inter-dominion trade exchanges in cash-crops and foodgrains alike, (c) 
New Delhi's position on the then-attempted regime changes in Tibet and Nepal, and (d) an assortment of socio-cultural themes. ${ }^{36}$ Secondly, the varied tones of this diverse coverage were as much issue-based as identity-related and were, above all, about "the difficulties of ordinary people or common people". ${ }^{37}$ While competitive nationhood was not absent, it was not simply a case of one-upmanship either, and in portraying India to its readers, The Pakistan Times was not solely focused on self-reflexive nationalistic stances or petty pro-establishment politicking but was also devoted to a nuanced treatment of social, cultural, ideological and economic issues. Finally, this collage is colored by telling cartoons; some coming from India's Shankar's weekly. ${ }^{38}$ At one level, representation on these topics shows the contextual "agency" exercised by the newspaper; at another, they showcase the content of its "influence"; at yet another, they provide a glimpse into the non-statist public sphere, which this article seeks to sketch with sympathy. ${ }^{39}$

However, before going any further, it ought to be kept in mind that English in Pakistan, like in India, was the lingua franca of the thin, top elite-establishment. Urdu papers like Jang had a far greater reach than their English-language counterparts, among whom The Pakistan Times' circulation remained between 8,000 and 34,000 in its dozen years of existence. ${ }^{40}$ Similarly, in terms of demographic distribution, the latter were "skewed toward the more liberal elite", while in terms of journalistic traditions of the time, the former, like their Indian vernacular counterparts, appealed "to the masses" and included "scandal sheets as well as respected journals, religious papers, and party organs", with honorable exceptions. ${ }^{41}$ A compilation done by Irfan Waheed Usmani of the “circulation figures" for West Pakistan's major dailies through the 1950s shows that Jang (Urdu, Karachi) and Dawn (English, Karachi) were the premier 
newspapers, followed by The Pakistan Times (English, Lahore) and its Urdu counterpart, Imroze. The older Civil and Military Gazette (1872, English, Lahore) and the younger Nawa-i-Waqt (1940, Urdu, Lahore) declined through this decade. ${ }^{42}$

This rise of The Pakistan Times owed not a little to Faiz. As Usmani notes "the PT grew into effective newspaper under his editorship" and confirms that Faiz "laid out the political creed" of the newspaper. This creed was "underpinned by radical ideals of 'people's supremacy', support for the marginalised and exploited classes, projecting the problems of peasants and the proletariat and orienting people to their fundamental civil rights". ${ }^{43}$ These ideas provide a theoretical thread running through the different sections of this article. Similarly, introducing a selection of articles, editorials and interviews of Faiz, compiled by the bibliophile Sheema Majeed, columnist Khalid Hasan called them "wedded to the ideas of a just and free society, where the powerful would not exploit the weak and where there would be dignity of labour, freedom of movement and association, and where no one would go hungry" ${ }^{44}$ Each of these beliefs echo in the topics presented below in different sections, wherein glimpsing the newspaper's contribution in the "public opinion" enhance our understanding of these exercises in state-building, sovereignty and nationalism in the Indian subcontinent in the aftermath of independence, whether it was about creating "consciousness" about the feudal order's exploitation of the society or foreign aid's encroachment upon the state. ${ }^{45}$

\section{“...On verge of precipice..."46}


The Pakistan Times covered the goings-on in its neighbour's biggest political party, Indian National Congress, more than the doings of the Indian government. And, with good reasons, for 1950 was the year of "great turmoil" for that party ${ }^{47}$ Used to a consensual leadership under its conscience-keeper Mohandas Karamchand Gandhi, Congress' faultlines were coming to fore since Gandhi's assassination in January 1948. The duumvirate at the top, ${ }^{48}$ Vallabhbhai Patel and Jawaharlal Nehru, were the two faces of this Janus-party and in autumn 1950, they engaged in a duel by supporting different candidates in the election for the post of the president of Congress. At stake was not merely the fortune of individual contestants, Patel-supported Purushottam Das Tandon and Nehru-backed Jivatram Bhagwandas Kripalani, or the prestige of their promoters but verily their respective idea(s) of India. ${ }^{49}$ More prosaically, it also amounted to Nehru's "search for power" within the Patel-dominated "Congress organisation", ${ }^{50}$ as he had been weakened by the departure of Congress Socialists in March 1948.

Given that Pakistan and the Muslim minority in India was the cornerstone of that contest, ${ }^{51}$ The Pakistan Times was keenly watching and analyzing the outcome: “Tandon's Triumph". Kicking off with a strongly worded editorial on September 5, 1950, the newspaper called it an "unfortunate occurrence", whose "only mitigating feature" was Tandon's "very narrow majority" (1306 to Kripalani's 1052 of the 2600 votes polled). Recalling Tandon's long association “with the most reactionary, communal and obscurantist elements inside the Congress" and remembering his "hostility and anger [at] his Muslim compatriots", especially on the Hindi-Urdu language question in his United Provinces (UP) ${ }^{52}$ it put into perspective his consistent opposition to "the establishment of a secular state" and demand of "cultural unification [by] transfer of population between the two Bengals". Tandon, a "childhood acquaintance and old UP 
colleague" of Nehru's, in other words, "would have turned the clock of history back a few thousand years". 53

Patel, despite sharing Tandon's views, had supported the April 1950 Delhi Pact, "which asserted the right of minority to equality of citizenship", ${ }^{54}$ but his backing now of thus victorious Tandon was being seen as "a defeat for Nehru", apart from revealing "great sympathy for a more Hinduised outlook" in the Congress. ${ }^{55}$ A "hurt and angry" Nehru wrote to another old UP ally thus: "Our province pains me most...Congress work has gone to pieces and our friend, Purshottam Das Tandon, goes about talking about Hindu culture and telling Muslims to adopt it". ${ }^{56}$ All this was a cause of concern for The Pakistan Times but it also gave it an opportunity to take a swipe at Chaudhry Khaliquzzaman, ${ }^{57}$ president of the Muslim League in Pakistan, whom it contrasted to Tandon as a "government yes-man". The party itself was akin to "unity among thieves", in Faiz's words. 58

The editorial perceptively noted that "the most unenviable position would be that of Nehru". However, this was not followed by any sympathy for the Indian Premier, who had "his own compromise, vacillation and inability to act strongly to thank", ${ }^{59}$ for his position. This articulation was in common with the feelings within the Congress Socialist Party (CSP) that Nehru had been an "ineffectual angel", and, had he "acted more positively...the election result might have been different". ${ }^{60}$ Still, if anyone provided hope, it was Nehru and the newspaper knew it. Ten days later, it wished that the Prime Minister would prevail upon his party. In the lead-up to the annual session of the Congress, held in the central Indian city of Nasik that year, Nehru had issued a statement, which aimed at limiting "public pronouncements" by Tandon on 
his two key objectives, "a cooperative Commonwealth" and the "Delhi Pact" ${ }^{61}$ Nehru's strategy was "to work... with Tandon but to ensure that Congress publicly stood by [his] policies". ${ }^{2}$

Reflecting on the statement in an editorial titled "Congress Policy" on September 14, 1950, the newspaper saw it as "an invitation to Congressmen to know exactly where they stand". Sharing Nehru's anxiety “over the 'spirit of communalism' in the country and the Congress”, it nevertheless remained suspect at this attempt "to purge the Congress", as it could not "naturally be achieved in a matter of weeks...months". This was especially so as Nehru did not "have the backing of a solid group" within the party and "much of his strength" came from "his prestige in the country". ${ }^{63}$ A week later, The Pakistan Times exhaled a small sigh of relief, when noting the adoption by the Congress Working Committee (CWC) of Nehru's statement, while explaining it archly that "an open break with Nehru" was not what the Congress old guard were seeking. After all, they knew that the Prime Minister's "radical phraseology [stole] the thunder on the Left". Of course, on India-Pakistan and majority-minority issues, Nehru's personal imprint on the policy gave succor and now, stamped by the Congress, helped "allay apprehensions" in Pakistan. ${ }^{64}$ This was more so as Tandon, in his presidential address at Nasik, had expressed a "get tough with Pakistan" line. This was another case of the party "running a country's government [speaking] with two tongues", ${ }^{65}$ and the newspaper was eager to limit Tandon's to khadi promotion and, as the cartoon below suggests, cow protection. [Cartoon: Tandon and Cow]

Overall, to The Pakistan Times, it seemed that the Congress' Nasik session failed "to give clear lead to people". The leadership issue was left ambiguous and, while the grand old party avoided the anticipated split, there was neither clarity nor dynamism on two key issues: (1) India- 
Pakistan relations and (2) economic questions. With respect to the first, a "peaceful resolution" combined with Nehru's "spirited speeches" made the newspaper hopeful. With respect to the second, Congress had adopted a "beautifully vague" resolution "which envisaged 'a mixed economy'...hunting ground for opportunists [and] the bitterest scramble for power" ${ }^{66}$ This tussle started within a fortnight, with Nehru reportedly refusing to join Tandon's Working Committee.$^{67}$ UP's "Muslim Opinion" seemed similarly in two-minds, if the results of three byeelections to the legislative assembly held then in UP's Muslim constituencies were to go by. Congress won one and lost one to a Socialist and another to a People's Congress candidate. But, this leftward trend among UP's Muslims could not be pronounced, for, as the paper perceptively noted, "a community victimised...cannot align itself with political elements which have incurred the displeasure of the ruling classes..."68

In mid-October 1950, Nehru agreed to join Tandon's Working Committee so as “to...ensure the implementation of [his] policy [by the Congress]". The Pakistan Times lauded his intent and then proceeded to remind him that "personal non-cooperation" does not always work against "wellorganised political opponents". Nehru had prevailed in Nasik because of his mass popularity but to persist he "must consolidate his political position inside [the party]" ${ }^{69}$ This was more so because, while Nehru chose to stay put, his defeated candidate JB Kripalani had moved on and "formed a Democratic Front within the [Congress]" on September 20, 1950, along with Rafi Ahmed Kidwai and approximately fifty other Congressmen. While applauding them, the newspaper remained rightly doubtful about the prospect of the endeavor, given Patel's "hold over the party machine, as Acharya Kripalani knows to his cost". Unless, Kripalani and others were "prepared to leave Congress". ${ }^{70}$ 
By mid-December 1950, they were. When Tandon asked Kripalani to refrain from factionalism, the latter replied that he was ready to "face the music". ${ }^{71}$ This split would materialize in mid1951, capping "a full year of acute controversy". ${ }^{72}$ Kripalani would leave the party in May and form a Krishak Mazdoor Praja Party (KMPP). Kidwai would follow him and Nehru himself would leave Tandon's CWC on August 11, 1951, forcing Tandon to resign in early September. ${ }^{73}$ For the moment, on the day that Congress' former and India's first President Dr. Rajendra Prasad turned 66, the newspaper gave space to Congress' most vocal and popular opponents. It quoted the till recently Congress Socialist leader Jayaprakash Narayan (JP),${ }^{74}$ calling the Congress in Simla "not a party of people but a conservative party controlled by capitalists and princes..." From nearby Amritsar, it was the Akali leader Master Tara Singh, ${ }^{75}$ who was reported taking aim at the "deep-rooted corruption in the Congress" as well as demanding "the creation of a Punjabispeaking province and recognition of Panthic entity". ${ }^{76}$

Ten days later however, all politicking quietened down momentarily, as The Pakistan Times headlined its front page with the news "Sardar Vallabhbhai Patel dead". It accorded the moment tremendous space from both India and Pakistan, with comprehensive columns prominently titled "Nehru's grief" and "Liaquat's tribute". ${ }^{77}$ On the second page, it carried "an appreciation" and a "life sketch" and, on page four, in the spirit of Faiz's editorial "Long Live Gandhiji!" from February $1948,{ }^{78}$ an editorial simply titled "Sardar Patel". It began in a dignified manner by noting that this was "no time to assess" Patel's "real role" in the subcontinent's political theatre. He had "passed from politics into history and the job had better be left to a historian's pen". It then went on to pay a rich, if chequered, tribute to Patel's 
...stupendous powers of resolution, action and command, ruthless intolerance of all opposition,

relentless pursuit of objective, political astuteness, efficiency in execution, cold-blooded realism and consistent distaste for sugar-coating of words...his... awesome solidity.

While acknowledging Patel's differences from and with Nehru, it asserted that it was the former "who kept the national political structure intact by appeasement or persecution...of the extremist elements" ${ }^{79}$ Indeed, “it was not until [Patel's] death that Nehru [was] prepared to make an effort to wrest control of Congress from the pro-Patel group, whose power was made manifest by Tandon's [Presidentship]"'. ${ }^{80}$ In September 1951, he would be anointed by the All-India Congress Committee as party president, fusing it with country's premiership and reversing "party control over government". ${ }^{81}$ Outside, the vocal extremist elements - JP was reiterating that "the constitution of India [was] a product of clever capitalist brains, feudal lords and rajas..."82 _ would be trounced in the general election of 1952. Inside, the "Congress "System"" was on its way, ${ }^{83}$ and it would be left to Feroze Gandhi, the Prime Minister's irrepressible son-in-law, to provide some irreverent commentary on it, which found prominent place in as impishly antiestablishment set-up as The Pakistan Times. [Cartoon: Feroze Gandhi and Nehru]

\section{“...A collection of undecided liberals and communal bigots, staunch nationalists, old-pro- Britishers and capitalist agents..."84}

When the fog of Partition passion started to lift, it became clear that the longest-lasting cut was going to be economic. While the old socio-cultural fabric in Punjab and Bengal was never truly asundered, their old trading networks were certainly shattered. These were now national issues, 
proclaimed and policed from Karachi and New Delhi respectively; a part of what has been recently called "the finality of partition". ${ }^{85}$ In autumn 1950 , the bone in the throat of IndiaPakistan economic relations was the rupee controversy that had hamstrung their trade since India had devalued its currency, following London's lead, in September 1949. The par value of the Pakistani currency, on the hand, had remained untouched with good reasons, as laid out by The Economist:

Pakistan's balance of payments with the rest of the world...is favourable... [It] has embarked on a process of industrialisation and needs to import capital goods cheaply... [It] believes that its exports have inelastic demand [and] finally, wants to bring about a fall in domestic prices. ${ }^{86}$

A year later, the matter was still unresolved. Finance Ministers of India and Pakistan at this time, Chintaman Deshmukh and Ghulam Mohammad, had been among the above-mentioned old-proBritishers. The latter had appealed to the former "to allow trade [overcoming] India's refusal to accept the Pakistan currency's external value" but The Pakistan Times was categorical that it was Ghulam Mohammad, who was responsible for the "present confusion", ${ }^{87}$ as he would neither rule out devaluation nor carry it out. An increasing trade deficit and the devaluation of the British pound had seen New Delhi, "as advised by [London]...devalue the Indian rupee". ${ }^{88}$ Pakistan, in a stronger position with its export surplus, had been "supported by the British in its refusal to devalue its currency". This was Machiavellian to the paper, which saw London's support

...aimed at effecting virtual severance of Indo-Pakistan trade relations which would not only compel Pakistan to turn to Britain for disposal of her raw materials but would also adversely affect Indian industry by closing its Pakistani market... ${ }^{89}$ 
In a detailed statistical picture of devaluation drawn in its editorial page on October 1, 1950, the newspaper began by pointing that India's adverse balance of trade, reduced by devaluation, was still four times greater than Pakistan, whose no-devaluation stance had brought a small surplus. ${ }^{90}$ The main cause of deficit was India's food imports; accounting for nearly 15\% during 1949-50. In their mutual trade too, India had an adverse balance, notwithstanding the absence of imports from Pakistan, after devaluation. The main item here was raw jute: the "one pillar" of Pakistan economy. ${ }^{91}$ Its import had fallen more than by a third but the newspaper noted that as raw jute was still reaching Calcutta's jute mills, this revealed "the extent of smuggling". ${ }^{92}$ There was no mistaking the central conclusion that India's devaluation on British advise had resulted in a substantial increase in the Anglo-American share in India's foreign trade, leaving Pakistan way behind and bleeding India's foreign exchange.

No wonder the headline on October 3, 1950 was "talks likely for new Indo-Pakistan trade pact on 'broader basis"”. Ten days later, both governments accepted the principal of "no war" and more trade, with arbitration agreed on their respective currencies' mutual value. ${ }^{93}$ But, trade was not the only thing that was in downturn in India. With the textile industry in slump, around 20, 000 workers in Bombay city were on strike for close to two months. At the hands of a repressive BG Kher ministry, it saw police firing that killed 2 and injured 8 workers. ${ }^{94}$ With this economic crisis worsening the aftermath of Partition, ${ }^{95}$ the first general election of independent India scheduled for April-May 1951 was postponed by the Nehru government in mid-November 1950 and Faiz, as before, sounded the bugle on this "retreat of democracy". 96 
Recalling in an editorial on November 16 that it was in 1945-46 that the present government(s) were voted into power in the provinces by $14 \%$ of the people in the then-restricted franchise, the newspaper remarked that the union government at New Delhi, "representing the indirect representatives of these $14 \%$ ", was thus twice-removed from the scales of popular representation. Congress itself had "changed considerably" since 1947, with JP-led Socialists no more a part of it. With these old comrades, many ideas that they stood for, had departed too. Three years and three months from independence, there was more famine than food across the country, with consequent starvation deaths. Production had fallen in many industries, followed by inevitable retrenchment and consequent unemployment. The flourishing black-market in consumer goods was an open secret, making "living costlier [with] wages stationary". There was a regime of preventive detention and banning/interning in place in Bengal, Bihar, Hyderabad and Madras, aimed at communists but affecting any/all dissenters/critics. This political climate had stayed the conservative Congress' hands regardless of an "impetuous and over-confident Nehru", as "people who failed to get bread under a government cannot be expected to vote for it". ${ }^{97}$

It is plain to see in the pages of The Pakistan Times that, in the winter of 1950, the food situation in India was causing concern and the government's handling of it was causing condemnation. Union Food Minister, KM Munshi was on tour of north Bihar; among the worst-hit provinces. There were "anti-black marketers" demonstrations on the streets in central India and "wordy duels" on the floor of parliament. ${ }^{98}$ Speaking there, Munshi said: "Our financial resources are limited. Our markets - Pakistan and Burma - have become foreign countries...We need faith to succeed in our great resolve..." This prompted Sardar Bhupinder Singh Mann, one of the Sikh representatives in the assembly, to quip: "What about [giving] work as opposed to faith?"99 
Munshi's lament recalled the wishful line of the Export Committee of the Partition Council that "until March 1948 India and Pakistan should 'give or receive supplies of controlled commodities as if there had been no Partition"”. ${ }^{100}$ In its tongue-in-cheek editorial column, "Between the Lines", the newspaper extensively remarked upon "India's food problem", with much sympathy for masses and much sarcasm for Munshi of whom, it wrote that "as Food Minister he was not paid for hunting up obscure Hindi names for such ordinary tasks as tree-planting”. Although Munshi's mandarins still spoke the language of "self-sufficiency by 1952 ", ${ }^{101}$ they had to "increase the [import] quotas". The extent of shortage could be gauged from the fact that "a surplus province like the UP asked for [central] allocation of 170, 000 tons". And, then The Pakistan Times let itself loose:

The Indian Government's "patriotism” has prevented Pakistan's surplus food from entering that country. This...helps only the black-marketers and hoarders and we suppose [they] have influence in high quarters to carry on the currency war...India still prefers to pay a higher price in the world's market rather than negotiate with Pakistan for a steady supply of foodgrains [italics in original]. ${ }^{102}$

This bi-lateral burst was not isolated. On the same day, in the same column, in another opinion piece titled "Joint Indo-Pakistan Defence", the newspaper took aim at "Britain's leading soldiers, politicians, and publicists", who never tired of "telling the two States that unless they agree on joint military measures, the Big Bad Wolves of the world will...devour their Independence". Reminding its readers that these "English experts on India and Pakistan...cannot possibly be ignorant of the existing situation, for they themselves were largely responsible for creating it" and reflecting that this call was basically aimed at a "'joint defence' of the British Empire", the column concluded bitterly thus: 


\begin{abstract}
Apart from the fact that this task can arouse no enthusiasm among the people of this subcontinent, a natural corollary to joint Indo-Pakistan defence under British auspices would be the return of British influence and British military experts - a danger against which Pakistan and India need to guard themselves, if possible, jointly [bold in original]. ${ }^{103}$
\end{abstract}

Meanwhile, with Munshi taking a hard line against both rural rationing and food imports despite damaged kharif crops, rural Maharastra and Gujarat were down to "three days ration" per week, while the government was holding on "to full rationing in cities". ${ }^{104}$ Things got worse before they could become better for a Hungry Nation, in which as Benjamin Siegel has recently shown, state promises of support got overlain by state requirements of self-help by the society. ${ }^{105} \mathrm{By}$ mid-December, it was clear that India was "facing mass starvation without import" and the “deficit states" were vocally opposing New Delhi's "self-sufficiency plan". Deliberations in the All-India States Food Minister's conference were deadlocked over "differences about abolition of rural rationing". An 8-man sub-committee ended similarly as "Bihar, Madras and Bengal stubbornly opposed the abandonment of rural rationing”. Munshi, supported by the surplus states, insisted on its "immediate ending" and stressed the "objective of stopping any food imports in 1952". To the food ministers of deficit states, this "idea was a dream", ${ }^{106}$ but, Munshi prevailed and the conference agreed to not import foodgrains from March 31, 1952. Accordingly, Madras and Bombay provinces were to abandon rural rationing regardless of the fate of thousands, ${ }^{107}$ which - for the moment - depended on India getting American foodgrains. ${ }^{108}$

In the new year of 1951, however, Munshi beat a retreat and announced that the aim of achieving self-sufficiency by a definite date would not be allowed to stop imports and cause starvation. 
This new realism was greeted with relief both in India and by The Pakistan Times. Liberalizing its regime of food imports, New Delhi was now looking for foreign food: wheat from America and/or the USSR, rice from China and/or Vietnam. The paper again reminded its readers that this “misery could have been avoided if [New Delhi] had not refused Pakistan's wheat [in] an unwarranted [disagreement on] the value of Pakistan's currency". ${ }^{109}$

It was not only food by now and shortage had spread to other essential stuff too. In January 1951, the central committee of the All-India manufacturers' organization at Bombay, passed a resolution of concern at the growing lack of "industrial raw material". ${ }^{110}$ In one instance - that of newsprint - New Delhi responded with a regulatory order "to economize the use". Other cuts followed, notably in defense, where the government decided to retrench 50, 000 auxiliary recruits and save precious crores from an expenditure, which was half the total revenue. ${ }^{111}$ The other side of this coin was an increase in fares in Indian Railways, though here too, as the newspaper bitingly noted, the government increased "one pie per mile in the third class railway fare". ${ }^{112}$ None of this could hide the fact that Bombay was "facing $25 \%$ food cut" and, following the abrupt end of rural rationing, black market prices had shot up. ${ }^{113}$ No wonder, in mid-January, even as Nehru rejected Commonwealth Premiers' move for Commonwealth forces for a plebiscite in Kashmir, his government approached Pakistan for a "resumption of trade". 114

Welcoming this "realistic" step "as opposed to the sentimental appraisal of economic facts", the newspaper hoped it would end the "present deadlock" that had "benefited neither". India had "not succeeded in finding an equally cheap source of raw material or an equally satisfying market for finished goods". Pakistan stood to "save a lot if [it sought] some essential 
requirements - coal, cotton textiles - from India rather than other distant sources”. Indeed, the only countries that had gained from this deadlock were Britain, the Anglo-Saxon Commonwealth and America. Both "sanity and self-interest" now demanded a face-to-face engagement, rather than face-saving, which was beneficial to both. ${ }^{115}$ After all, some kind of barter trade had endured "in east Pakistan [of] jute, timber, potatoes, betel-leaves, bidi, fresh-dry-salted fish, milk/products, raw hides/skins, eggs/poultry - all without licenses..."116

By the end of January 1951, food ration all-over rural India was cut down by $25 \%$, and prices were pushed up by $15 \%$. While officially the policy of achieving self-sufficiency was not abandoned, attempts were being made "to buy foodgrains [from] wherever available". This now included Pakistan, for the alternative was the US and its high price. India did not have enough dollars and had asked for "an easy-payments scheme". America was prepared to give food as "free gift", if New Delhi subordinated its foreign policy to Washington, against the backdrop of the Korean War. ${ }^{117}$ The Pakistan Times carried an extract from an article published in The Statesman (Calcutta) written by JJ Singh, President of the India League of America and put its implication firmly: "American food is available...It is a barter agreement and India is expected to hand over her freedom". ${ }^{118}$ It was a different kind of balancing act to below: [Cartoon:

\section{"BALANCE YOUR FOOD"]}

In February 1951, Indian textile magnates exacerbated this economic situation by threatening mill closure in lieu of "further increase in cloth prices". This action, "full closure of 5 mills and part closure of 3 throwing 5000 workers out of employment without any notice", was on the stated reason of "shortage of cotton". ${ }^{119}$ This was another reason for the "trade deadlock", now in 
its seventeenth month, ${ }^{120}$ to be broken. HK Mahtab, union Industries \& Supply minister, was expressing the view that "many of India's present economic difficulties would be removed if there was free trade again with Pakistan" and the newspaper welcomed "Mahtab's fervent hope" ${ }^{121}$ Its content could be ambivalent in its radicalism but it was unambiguously "antithetical to vested interests" of all kinds, while for Faiz it also amounted to the resumed "progress of a dream". ${ }^{122}$ From the other side, preparing for a barter deal in which coal was to be exchanged for jute, the redoubtable Economic Weekly prophesized thus: "Severe dents have been made on trading by the exchange deadlock but it has not been completely destroyed; nor can it be". ${ }^{23}$

\section{The "halting introduction of democracy"}

It was, however, neither the vicissitudes of a political party nor the vagaries of government policies within which was limited the varied representation of India/Indian in the pages of The Pakistan Times, under the editorship of Faiz. It was the wider socio-cultural sphere in which the newspaper scored, with its range in reportage and remarks. A representative round-up of news from India comes from page nine of the paper for January 9, 1951, which was populated by the following rainbow of headlines:

Communist activity increases in South India: Congress leader NG Ranga's tour impressions, Hyderabad hospitals deprived of medical equipment, 15 people of Dravida Federation taken in preventive police custody in Madras, Begum Para prosecuted for rash driving in Bombay, India's record tea production, and, World Engineering Conference in Delhi from January 10. 
Whether it was a near full-page coverage of "Gandhiji's birthday celebrations in Lahore", at the Indian Deputy High-Commissioner's residence, ${ }^{124}$ carrying fulsome praise of the multi-faith prayer gathering and comments from a large number of attendees headed by Sufi Abdul Hamid, President of the Punjab Muslim League, or the editorial page on the same day carrying an article titled "Gandhi - a maker of moulds", alongside Tagore's famous song "Walk Alone - a favourite with Gandhijil" - or a warm welcome to Maulana Hasrat Mohani (the sloganeer of Inquilab Zindabad and poet of Chupke-chupke raat din aansoo bahana yaad hai) in Lahore, the newspaper's coverage was remarkably wide. Mohani, member of UP's legislative assembly and former member of the Indian Constituent Assembly, ${ }^{125}$ was on his way back to India from the Haj pilgrimage and the progressive poet was a person after Faiz's own heart. An example is the prominence that his following words were given:

\footnotetext{
Communism and religion were not incompatible with each other. Communism is a political and economic theory, whereas religion is a matter of faith in God. Eliminate all the evils from Communism and you have Islam [bold in original]. ${ }^{126}$
}

The newspaper's celebration of communism was not limited to its invocations from visitors but included editorials like the one on November 8, 1950 titled "New life \& new vistas for two hundred millions: Achievements of 33 years of Socialism in Russia". ${ }^{127}$ Next day’s editorial page carried a literary obituary of George Bernard Shaw by Qurratul Ain Haider, well-known Urdu short story writer and novelist of Aag ka Darya. ${ }^{128}$ The Sunday magazine of November 12, 1950 carried a report on the great Chilean Pablo Neruda's visit to Delhi. The 46 year old poet-in-exile had received a warm public reception in which he spoke about "the deep bonds between the writers and the people...workers, miners, farmers, seamen...the need to write simply and 
directly so that the common people might understand [bold in original]". ${ }^{129}$ Faiz, a kindered internationalist spirit, who penned editorials titled "the writer's choice" and "decolonizing literature", would remonstrate in 1955 against "the neo-imperialist power bloc [and] apprenticeship to the Cold Warriors", which broke "the trade union movement and the labour leadership". ${ }^{130}$

Meanwhile, Mohani, the UP Muslim who had stayed back in India seemed to be faring better politically than Khaliquzzaman, the UP Muslim who had abruptly left for Pakistan. In the first week of October 1950, he was unceremoniously deposed as the president of the Muslim League, as Prime Minister Liaquat Ali Khan, like his Indian counterpart, sought to consolidate his position by becoming party president. ${ }^{131}$ On the same day, it was reported from Calcutta that Jogendra Nath Mandal, the Scheduled Caste member of Liaquat's cabinet from East Bengal, had resigned and was likely to adopt Indian citizenship. ${ }^{132}$ The editorial on October 11, 1950 was devoted to dissecting "Mandal's Diatribe". ${ }^{133}$ Mandal, associated with the Muslim League since 1943, had also been a member of the pre-partition Interim Government (September 1946-August 1947) and had been a touching rod for "Pakistan's treatment of minorities". ${ }^{134}$ He had been “opposed to [Pakistan's] establishment while a League minister in the [interim] government" and The Pakistan Times was not willing to accept that he had been "a virtual prisoner...against his conscience for...three years", before claiming "frustration and disillusionment". Stressing the timing of Mandal's departure, it asked, "Was it not his duty as an advocate of the rights of the minorities, the SCs, to refrain from doing things which...exacerbate communal feelings?" To reaffirm this point, it carried speeches from the minority leaders in the North-West Frontier 
Province (NWFP) (Lala Kotu Ram), Baluchistan (Chaudhuri Tekka Ram) and Punjab (CW Tresler), ${ }^{135}$ to show that minorities were among the focal points of "its socializing agenda". ${ }^{136}$

Apart from this much-remarked communalism in both countries, the fate of his communist comrades in India also occupied a prominent place in Faiz's attention. This depended on two things: one, internal dissensions of the Communist Party of India (CPI), ${ }^{137}$ and two, institutional repression of it by the Indian state. ${ }^{138}$ There were parallels to be drawn here with the Pakistani state, whom Faiz regularly charged with "murdering freedom" and "coordinated oppression", while challengingly asking it: "what price liberty?"139 By the end of 1950, the CPI had been reeling under both and looking to make a fresh start. Party's central committee "reversed all its decisions...taken during the last two years and reopen[ed] the case of [former general secretary] PC Joshi's expulsion [in 1949]". ${ }^{140}$ Another commission was appointed "to enquire into the conduct of [Joshi's successor] BT Ranadive and four other members of the old Politburo". ${ }^{141}$ The Third Party Congress was to be held in 1951 and the politburo

...pledged to work for the united front of all left parties [and] called upon the people to defeat the game of the government in postponing the election, to demand the removal of ban on the CPI, release of political detenues, and repeal of security laws to enable all sections to participate in election. ${ }^{142}$

With the passage of the new constitution in January 1950, the fate of these political detenues took a turn for the better. ${ }^{143}$ In January 1951, 865 communists' detenues were released in West Bengal, after the Calcutta High Court declared such preventive detentions to be constitutionally untenable. 88 other communists, detained under a criminal law, were also similarly released. The ruling also heralded "the end of the ban imposed on the CPI in West Bengal in March 1948", 
welcomed by The Pakistan Times. ${ }^{144}$ In mid-January 1951, the first communist rally in three years was held in Calcutta where the future Chief Minister Jyoti Basu presided, stressing the "need for unity". The call was heeded to by other left groups like Democratic Vanguard, Socialist Republic Party, Forward Bloc and Radical Humanists. ${ }^{145}$

Taking a cue, in Telangana, a mass petition grew asking for pardon for the 12 peasants sentenced to death for their alleged communist activities. ${ }^{146}$ Noted British lawyer and Labour party leader, DN Pritt appeared before the Supreme Court of India in February 1951 on behalf of them. ${ }^{147}$ Jayasurya Naidu, son of the poet-nationalist Sarojini Naidu, was chairing a Telangana Defence Committee appealing for a fair trial, as the death sentence was passed by a special tribunal "within 3 hours, without legal defence". Naidu warned that these heavy-handed measures were likely to fail without following land reforms and revealed that he had passed on to MajorGeneral JN Choudhury after the "military take-over in Hyderabad" in September 1948, "a request by communists to halt action”, which was not reciprocated. ${ }^{148}$

Taken together, these developments would culminate in the first amendment(s) to the Indian constitution in early-1951. ${ }^{149} \mathrm{~A}$ legislative bill to amend detention act was moved in February, in light of judicial highlighting of the Fundamental Rights to liberty and property. A Central Preventive Detention Act of 1950 was reformulated and extended by one year, alongside some of its provisions being liberalized, for example, "reference of detenues to mandatory advisory boards within 6 weeks [and] temporary release of detenues on parole". In December 1950, there had been about 3000 people under detention in India, among whom only a few cases had been processed thus. ${ }^{150}$ At heart though, both these issues were about feudal land, princely property, 
and a lack of equitable reform in them despite independence and the new constitution and The Pakistan Times did not miss that. ${ }^{151}$ Faiz always wrote demanding editorials on the theme of "land and the tiller", ${ }^{152}$ and in a pungent entry on "India's Princes", the paper called out their "unique trade union [for] safeguarding [their] rights", turning rebellious "following Patel's death". It had drafted a "grandiloquent code of the 'privileges and dignities' that [New Delhi was] expected to recognise". The newspaper was on the point when it noted that

...liquidating the princely states was not taken to its logical conclusion...far too much power was left [with] the rulers...the Congress ministries have not been [ameliorative]. The Princes have also received encouragement from reactionary organisations like the Hindu Mahasabha...the real solution lies in divesting the princely puppets of special privileges that they still enjoy in a republican India. ${ }^{153}$

The counterpart to this in the provinces was Zamindari. Congress had been pledged to its removal from before independence, but it had been easier said-than-done. ${ }^{154}$ When in January 1951, the UP government finally sought to bite the bullet, it was dressed up as an expensive give-and-take. More than 2 million absentee landlords in the UP were to receive an equivalent of 110 million sterling under a legislative bill, which was expected to "release more than 7 1/2 million peasants from "feudal bondage",. ${ }^{155}$ This rushed bill was intended to be a "revolutionary" gift on the first anniversary of the Indian republic but was a belated, half-baked delivery of a long-made promise that was subject to legal lacunae. It thus risked increasing rural discontent. In effect, the UP-Zamindari Abolition Bill was “.... a mild step... [It did] not even pretend to help the landless labourers... The rate of compensation, at eleven times the annual rental, [was] so high that only a fraction of the tenants [would] be, able to acquire bhumidari rights..." For the newspaper and its stance of "nuanced nationalisation", ${ }^{156}$ here was a salutary aspect - the 
compensation problem - for "those of Pakistan's land reform enthusiasts who... seek to help the tenants without hurting the landlords". ${ }^{157}$ Its limited impact was revealed when the Sugar industry in UP was left paralyzed by 70, 000 workers going on strike across 40 mills. ${ }^{158}$

In late-January 1951 came a news, from seemingly nowhere that the Indian industrialist GD Birla wanted to set up a textile mill in Pakistan's NWFP, while another, Sir Shri Ram, was prepared to extend his Delhi Cloth Mill mills at Lyallpur, Punjab by 30,000 spindles. ${ }^{159}$ This possibility of "Indian capital in Pakistan" appears impossible today, but, back then, seemed a "very real possibility...warmly welcomed by Chaudhury Nazir Khan, the Industries Minister". The Pakistan Times' objections to the import of foreign capital, whether Western or Indian, remained same and firm. It instead wanted the government to abolish "landlordism". ${ }^{160}$ Whether an "honourable existence" for minorities in either countries or the poor of both being asked "to 'gird up' their loins", the newspaper was consistent in standing up for those who could not themselves. ${ }^{161}$ Its concern for those on the margins, whether political or social, saw it giving space to socialists, ${ }^{162}$ at a time when space was shrinking for them both inside and outside their organizations and nations.

\section{Inheriting "British imperialism's 'responsibilities"'163}

While Kashmir and Korea were the big near-identity crisis and farther ideological dispute that occupied the pages of the papers in the Indian subcontinent at this time, events in Tibet and Nepal between October 1950 and January 1951 offer an over-shadowed twin that bring out the thread of solidarity with popular anti-colonial and anti-feudal upsurges present within the pages 
of The Pakistan Times. ${ }^{164}$ The common countervailing factors here were the establishment of the People's Republic of China in October 1949 and the evolution of the British bequeathed frontiers into the borders of independent India. This particular bequest had emerged from the half-century long triangular contest on their border: McMahon line. ${ }^{165}$ Declaring on its front page that "liberation forces [were] 100 miles from Lhasa" on November 5, 1950, ${ }^{166}$ the newspaper argued in its accompanying editorial that on China's position on Tibet "Indian...appraisal [had] been guided by the record left behind by the British Government...rather than by regard for a friendly and equal neighbour". ${ }^{167}$ A week earlier, the newspaper had produced a stinging cartoon on "Indian logic", echoing some of the perspectives that would eventually contribute to "the SinoIndian war of 1962". ${ }^{168}$ [Cartoon: "Indian logic"]

As Lhasa fell in the first week of November 1950, Tibet was replaced by Nepal in the headline on the front page: "King of Nepal flees Palace: Asylum sought in Indian Embassy" ${ }^{169}$ Two days later, an editorial "Nepal and India" followed, setting out a clear-eyed description of what had happened. The powerful Prime Minister of Nepal, Mohan Shamsher Jung Bahadur Rana, "the country's de facto ruler”, had upstaged the King Tribhuvan Bir Bikram Shah in a palace coup and had placed on the throne Tribhuvan's younger grandson, Gyanendra; then a three-year old boy and destined to be the last King (2001-08). Nepal had been locked in a treaty regime with first the East India Company and then the British government in India since 1815-16, which saw Gurkha soldiers, in the blunt words of the editorial, "sold as common fodder to the British, and later to the Indian Union”. This securing of social, cultural, military and economic ties had seen the ruling Ranas personally participate on the side of the Company in the revolt of $1857 .{ }^{170}$ Since then, they had successfully resisted all radical political change, while contributing " 55,000 
Gurkha recruits during WWI". This led to the "reward" of 1923 treaty "explicitly recognising Nepal's independence", further "securing the loyalty of Gurkha troops". ${ }^{171}$ Subsequently, "200, 000 Nepalese served" in the second world war, ${ }^{172}$ earning the country a sum of 2 million rupees as a subsidy from a grateful London.

However, the Ranas could not stop the "exposure of Nepal's people" to their neighbours and, in the early-1930s, a Nepal Praja Parishad (People’s Council), blessed by Tribhuvan's open dissatisfaction with the Rana rule, had been formed. It strengthened in the early-1940s and was followed by an All India Nepali National Congress (NC), set up in October 1946 at Banaras. The latter merged with the Calcutta-based Gurkha Congress and the Banaras-based Nepal Sangh in January 1947, under the leadership of BP Koirala, and begun agitating among workers of the jute mills at the border town of Biratnagar in summer 1947. They had "strong ideological sympathies, and personal ties with Indian Nationalists", ${ }^{173}$ especially the Congress Socialists from UP and Bihar. In fact, almost 500 Congressmen - including JP - had "fled into the Tarai" region of Nepal after Congress's Quit India movement in 1942-43, before being captured by the Rana troops and being handed back. In turn, Nepali activists had participated in the Quit India movement, "calculating that until India was free, Nepal would not be able to oust the Ranas". ${ }^{174}$

After the transfer of power in India, Nehru's government was caught in a bind because while the Congress Socialists from UP and Bihar gave support to the Nepali nationalists in their midst, it had to maintain close relations with the Rana regime and keep a watch on Nepali patriots in India. The now nationalist New Delhi, once again, felt an inheritance of "the imperial legacy of influencing Nepal's affairs [but] was more sympathetic to accommodating forces of freedom". ${ }^{175}$ 
Upon its nudging, in January 1948, "plans for a new constitution [and] elected assembly [were] announced", only to be scuppered by Mohan Shamsher in April. NC and the Kathmandu-based Praja Panchayat were banned and New Delhi acquiesced, for "however much India might have liked to see a democratic Nepal, it was also eager for stability on its northern border at a time when the Communists were on the verge of winning in China", ${ }^{176}$ and a Nepal Communist Party was being formed. In return, Kathmandu "allowed the use of Gurkha troops to help maintain order in northern India in 1949 while Indian forces moved against the Nizam of Hyderabad". In an echo of 1923, it was rewarded with "security and commercial agreements in 1950". 177

This treaty of peace and friendship of July 1950 saw the Nehru government encourage the Rana to take steps towards a slow and limited democratisation. Tribhuvan supported the idea, "for he had little to lose" by a reduction in the power of the Rana, who naturally refused and instead reentrenched himself. By now, the shadow of a Chinese Tibet loomed over New Delhi's attitude towards Nepal's affairs. If the latter could be democratic, so much the better but otherwise, it was correctly clear to The Pakistan Times that in this "strategically important country, India [had] no intention of helping the people to attain democracy". ${ }^{178}$ Meanwhile, however, jockeying family dissidents among the Ranas had funded a Nepali Democratic Congress in Calcutta and merged it with the NC in spring 1950, encouraging a "fighting force [with] tacit approval [and] deniability from New Delhi". ${ }^{179}$ [Cartoon: “The Stepmother's argument”]

Events developed quickly in Nepal. In a comprehensive, front-page coverage, the newspaper reported on November 12, 1950 that even as the NC volunteers occupied Birgunj, the "second biggest town in Nepal", setting up a "parallel government', Tribhuvan was being feted in New 
Delhi. It further reported that about 2000 Nepalis in Calcutta, 1000 in Darjeeling, 300 in Banaras and 300 in Patna had "volunteered" to take part in the uprising. ${ }^{180}$ It was followed by a long editorial on 15 November, titled "Happenings in Nepal”, which began by charging "India, Britain and America, who maintain embassies in Kathmandu", of desiring "a plaint regime"; a desire "heightened by recent Tibetan developments". While America's interest was geopolitical, Britain and India were also concerned about their continued "recruitment of Gurkhas". India had one additional reason: its internationally recognized claim that Nepal's "internal stability, security [and] character of government [was] intimately linked with the defence of India's northeastern borders". Thus, India had played it both ways i.e. "lent its support to the anti-Rana camp", while maintaining inter-governmental relations with the Rana regime. The newspaper was clear that in the offing was a

...superficial change... substituting a constitutional monarchy for feudal autocracy... when the Nepali Congress and the dissident Ranas pull in opposite directions [in] the "people's government under the aegis of the King of Nepal", the King may assume more powers... ${ }^{181}$

In the five days between November 18 and 23 1950, news from and opinion on Nepal was published no less than six times, showing how much importance The Pakistan Times gave to it. Taking the Anglo-Americans to task over their understanding that Nepal was "primarily India's problem", it caustically drew parallels with "Korea, Japan, the Philippines [being] America's problems or Malaya, Burma, the African Protectorates [being] Britain's problems”. For it, Nepal was "primarily a problem of the Nepalese people" and if they were "delivered from the frying pan of the Prime Minister's dictatorship to the fire of an India-controlled monarchy", little would have changed: "The feudal aristocracy will continue to fleece the people, Indian businessmen 
will rush in to exploit 'freed' Nepal and the Gurkhas will continue to serve as cannon fodder for the Indian and British armies". ${ }^{182}$ This was consistent with Faiz's charter of demands from the Pakistani state, “...the right to vote, no distinction between the rich and the poor, freedom...the common heritage of us all, democracy...that knows neither handicap nor preference [nor] privilege..." 183

It suited New Delhi that Tribhuvan was "sympathetic towards...democratic reforms". It could "support [him] as constitutional king", to a Nepali Congress, prepared to accept him thus. Still, as recently as in July 1950, Mohan Shamsher had been in Delhi negotiating a treaty and MP Koirala of the NC “often complained of India's association with Rana". The latter's daughter was married to Karan Singh, the Dogra prince of Kashmir. Thus, the newspaper recognized that there was "no likelihood of India's going the whole hog" either way. New Delhi seemed to be running with the hare and hunting with the hound. It had allowed MP Koirala to enter India with Rs. 35 lakhs looted from the Birganj treasury only for him to be searched and detained at the Delhi airport. Therefore, in future, if not bearing "family resemblance with the Indian princely states", Nepal had "to be the buffer state between the Red Flag and the Tri-coloured Flag". ${ }^{184}$ And, so it was. News came on November 21, 1950 that the NC rebellion in Birganj had suffered defeat at the hands of state troops and the "9 day revolt aimed at the overthrow of the 85 year old Rana regime [had] collapsed". ${ }^{185}$ Two days later, in three pieces, the newspaper tried to make some sense of the unraveling scene. While it had become clear that any Indian sympathy with the NC was self-interested and politically expedient - it "feared a revolt more militant and radical" the "unpleasant prospect of an unfriendly regime" made New Delhi face a difficult choice between recognising "the baby King" with Rana or reinstating "the old King" without. ${ }^{186}$ 
By early December, the popular revolt had petered out but not the "factional tussle between two feudal cliques [nor] foreign domination [and] feudal oppression". It was complicated by a difference in opinion between Britain and India. While the latter held to Tribhuvan and the NC for a stable Nepal, Britain seemed to be "supporting the [Rana] and the three-year-old King". Chinese Tibet had "spurred [both] India's use of democratic slogans [and] Britain's imperialist interests". ${ }^{187}$ New Delhi complied with the Koirala-led insurgents, letting Congress Socialists to give "material help [and] moral support" to them, and "advertised [Tribhuvan] as sympathiser of the 'down-trodden"'. ${ }^{188}$ But, New Delhi's preference for a negotiated compromise between Rana and Tribhuvan also meant that it "clamped down on the NC fighters" denying them road and rail facilities and Birganj was thus recaptured by Nepalese troops in late-November. However, with Mohan Shamsher unrelenting, Nehru's government then "relaxed control of NC activity [and] rebel forces took Biratnagar and penetrated deep into the eastern hills". ${ }^{189}$

In the first week of January 1951, there was a "mass surrender of government troops on the Kosi” and, with Rana on back foot, ${ }^{190}$ The Pakistan Times, "abandoning euphemisms", was confirming the dominance of "India over Nepal". With an "unwilling" America and an "unable" Britain, a Delhi Compromise was now foisted at Kathmandu. It provided for a constituent assembly, a nine-member cabinet including four popular representatives and the titular King Tribhuvan and was "basically a rapprochement between two wings of the Nepalese autocracy". With pro-India elements in Nepal inside the government, Indian supervision was guaranteed. Gurkhas were to continue to serve British and Indian armies and no mention had been made of "abrogating the feudal land-tenure". As the paper put it well, "the loot of the Ranas [was] now to 
be shared differently". ${ }^{191}$ A week later, in a final salvo, it noted that with the promised constituent assembly not to materialise until 1952, the rebels of 1950 were being given “conditional amnesty and political freedom" for now. Although, sections in the NC remained reluctant to call off their campaign, perhaps "for fear of losing their following", they and the Nepalese people were "caught in the twin grip of an indigenous feudalism and a near-foreign imperialism". New Delhi was firmly in saddle as "the Nepalese people's self-appointed conscience keeper...over-lord"; ${ }^{192}$ a role it would play till early-2000s. By December 1951, the Rana - called "a wrong person at a wrong time"193 - was in exile in India, where he died in 1967.

The political dynamic of the forty years following the overthrow of the Rana regime was basically the result of this interaction among three forces: "the monarchy [along with Rana aristocracy and the army], the political parties, and the Indian government... seeing Nepal primarily in terms of border security". ${ }^{194}$ This last has not changed through the multi-party democracy since 1991 and the rise of Maoists in early-2000s. India's mediatory role in Nepal has always had "its own political interests" at heart. In 1951, it "saw the end of Rana's aristocracy" but also ended the beginning of the "popular revolution of that time" by hammering a powersharing arrangement; ${ }^{195}$ a revolution that would materialize in a different form in the $21^{\text {st }}$ century. The Pakistan Times' reportage and commentaries, if at times patriotic, reflect well the challenges of devising military strategies, determining social awareness and delivering political communication "about the need for structural changes in society". ${ }^{196}$

\section{"A stranger in the house"}


On February 23, 1951, Faiz Ahmed Faiz attended a meeting at Major-General Akbar Khan's house, along with Sajjad Zaheer of the Communist Party of Pakistan and some others. It was this rendezvous that was reimagined by the Pakistan state as a communist plot against it and renamed as the Rawalpindi Conspiracy Case. ${ }^{197}$ Alongside others, Faiz was “arrested between 9-10 March". A Special Tribunal was set up and “delivered its verdict on 5 January 1953”, sentencing Faiz to four years' imprisonment. ${ }^{198}$ He would be released in April 1955 and resume his editorial duties in February 1956 but he "never quite overcame his forcible eviction". ${ }^{199}$ He was succeeded at The Pakistan Times by Mazhar Ali Khan who, articulating the widespread "shock...surprise amounting almost to incredulity" at this "sensational [but] general charge", editorialized thus: "Arrests for purely political motives or to overcome a political crisis not unknown in this country...we demand a proper trial not merely because [of] principle of justice but, far more important, [for] public confidence and morale". ${ }^{200}$ As Kamran Asdar Ali has argued,

... whatever role Faiz may have played in the Conspiracy, the Pakistani press favourable to the state and the British intelligence agencies played up his central role [as] the most obvious threat...not formally a member of the Communist Party [but] the editor of one of the most influential dailies... ${ }^{201}$

In April 1959, with Faiz again detained since 1958, The Pakistan Times perished, under the Ayub Khan regime, "on the trumped-charge of receiving funds from 'foreign governments"”. As Saadia Toor notes, it was always "home to leftist[s]" but "after the Communist Party of Pakistan was banned in 1954, it was the Left in West Pakistan". ${ }^{202}$ The new editorial line was revealed on April 19, when it justified the takeover in following words: "Distant orbits and alien horizons...exercised a charm on...this newspaper, which gradually began to look like a stranger 
in the house..." ${ }^{203}$ At least some part of this strangeness was the kind of things the paper presented about the neighbour next-door as this article has tried to show - as Irfan Waheed Usmani has noted, it was the "bell weather of liberal public opinion"204 - be it the acute commentary on the contradictions of intra-Congress and inter-Congress politics in the delayed lead-up to the first general elections, correct analysis and anticipation of the restoration of trade exchanges between the two estranged and deficient economies/currencies, perceptive position on New Delhi's attitude to the then-attempted regime changes in Tibet and Nepal, and, a range of progressive reportage on miscellaneous themes. It reported, as Walter Lippmann wrote, "the world that... [was] politically out of reach..." ${ }^{205}$

At another level, while print culture's "implications for nationalism, modernity and colonial politics", ${ }^{206}$ have been offered repeatedly, this article has tried to sketch its impact on postcolonial politics, state-society interplay and the possibilities that existed in the English print sphere of early Pakistan of which The Pakistan Times was a prominent part. In focusing on a somewhat neglected aspect of scholarship surrounding Faiz, it has sought to highlight the significance of The Pakistan Times and, in doing so, to add to the socio-cultural contextualization of Pakistan-India relations during a relatively early and rare passing phase of agreement. Just as news in empire was shaped in a piece-meal manner by "imperial politics, capitalist enterprise, and individual agency", ${ }^{207}$ so reporting news and presenting views in an immediate post-imperial polity was a site of contested practice and complex discourse. Amidst this space, this article has sought to enliven a first draft of history through engaging with a newspaper's editorials, commentaries, cartoons and reportage. Finally, as news became a commodity of an ever-widening public sphere, its well-dissected "power to influence the 
imagination of an entire nation" came to the fore, ${ }^{208}$ a tool as much in the "anti-colonial struggle" as for a post-colonial strengthening. The Pakistan Times partook in this process in a "patriotic idiom" alright but always "ingeniously to further its socializing agenda", ${ }^{209}$ thus trying to engage the elite and resist the establishment on reflections of home and representations of the neighbour.

${ }^{1}$ See Lucy Maynard Salmon, The Newspaper and the Historian (New York: OUP, 1923).

${ }^{2}$ Ann Stoler, Along the Archival Grain: Epistemic Anxieties and Colonial Common Sense (New Jersey: PUP, 2010).

${ }^{3}$ See Chandrika Kaul, Reporting the Raj: The British Press and India, c. 1880-1922 (Manchester: MUP, 2003).

${ }^{4}$ Aurobindo Mazumdar, Indian press and freedom struggle, 1937-42 (Hyderabad: Orient Longman, 1993) and

Chandrika Kaul (ed.) Media and the British Empire (London: Palgrave Macmillan, 2006).

${ }^{5}$ See the special issue "Explorations in Modern Indian History and the Media", Media History, 15: 4 (2009).

${ }^{6}$ See Pippa Virdee, "Negotiating the Past: Journey through Muslim Women's experience of Partition and

Resettlement in Pakistan", Cultural and Social History, 6: 4 (2009), pp. 467-84.

${ }^{7}$ Sarah Ansari, "Everyday expectations of the state during Pakistan's early years: Letters to the Editor, Dawn (Karachi), 1950-1953”, Modern Asian Studies, 45: 1 (2011), pp. 159-78.

${ }^{8}$ Roger D. Long, "Dawn and the creation of Pakistan", Media History, 15: 4 (2009), pp. 407-21.

${ }^{9}$ Vazira Fazila-Yacoobali, “A rite of passage: The partition of history and the Dawn of Pakistan”, Interventions: International Journal of Postcolonial Studies, 1: 2 (1999), pp. 183-200.

${ }^{10}$ Ilyas Chattha, "Partisan Reporting: Press Coverage of the 1947 Partition Violence in the Punjab", South Asia: Journal of South Asian Studies, 36: 4 (2013), pp. 608-25 and Raghuvendra Tanwar, Reporting the Partition of Punjab 1947: Press, Public and Other Opinions (New Delhi: Manohar, 2006).

${ }^{11}$ Jan Chovanec and Katarzyna Molek-Kozakowska (eds), Representing the Other in European Media Discourses (Amsterdam: John Benjamins, 2017).

${ }^{12}$ Devika Sethi, "Press Censorship in India in the 1950s", (New Delhi: NMML 2015), available at http://125.22.40.134:8082/jspui/handle/123456789/878 [accessed January 24, 2019] and Robin Jeffrey, India's Newspaper Revolution: Capitalism, Politics and the Indian-language Press, 1977-1999 (London: Hurst, 2000). 
${ }^{13}$ Irfan Waheed Usmani, "Print Culture and Left-wing Radicalism in Lahore, Pakistan, c. 1947-1971”, PhD. Thesis

(NUS, 2016), pp. 144-98.

${ }^{14}$ Yoginder Sikand and SH Khan, "Indian Muslims and the mass media: report on a seminar", Institute of Muslim Minority Affairs Journal, 15: 1-2 (1994), pp. 187-91, Avinash Kumar, “Mass Media and Muslims in India:

Representation or Subversion”, Journal of Muslim Minority Affairs, 31: 1 (2011), pp. 59-77, Usharani Narayana and Priti Kapur, "Indian Media Framing of the Image of Muslims", Media Asia, 38: 3 (2011), pp. 153-62 and Saifuddin Ahmed, "New media, movies and anti-Muslim prejudice", Asian Journal of Communication, 27: 5 (2017), pp. 53653.

${ }^{15}$ See Sarwet Rasul, Language and Gender Stereotypes: A Study of Pakistani Newspapers (Lahore: Lambert, 2012) and Jawad Syed, "The representation of cultural diversity in Urdu-language newspapers in Pakistan", South Asia: Journal of South Asian Studies, 31: 2 (2008), pp. 317-47.

${ }^{16}$ Philip Oldenburg, India, Pakistan and Democracy: Solving the Puzzle of Divergent Paths (London: Routledge, 2010) and http://asu.thehoot.org/research/media-monitoring/how-pakistans-dawn-covers-india-9442 [accessed January 24, 2019].

${ }^{17}$ See the media coverage from 14 to 28 February 2019.

${ }^{18}$ Haimanti Roy, Partitioned Lives: Migrants, Refugees, Citizens in India and Pakistan, 1947-65 (New York: OUP, 2013), Sarmila Bose, Dead Reckoning: Memories of the 1971 Bangladesh War (Oxford: OUP, 2011) and Gyan Prakash, Emergency Chronicles: Indira Gandhi and Democracy's Turning Point (New Jersey: PUP, 2019).

${ }^{19}$ Chattha, "Partisan Reporting", p. 623.

${ }^{20}$ Usmani, "Print Culture and Left-wing Radicalism in Lahore, Pakistan", footnote 157, p. 66.

${ }^{21}$ Ibid. p. 90.

${ }^{22}$ He had set up Progressive Papers Limited in May 1946 and would establish Azad Pakistan Party in 1950. See Abdullah Malik, Sawanih Mian Iftikhar-ud-Din, Aalmi Communist Tahrik, [Biography: Mian Iftikhar-ud-Din, International Communist Movement], (Lahore: Kausar Publishers, 1985). Also see https://blogs.tribune.com.pk/story/31962/mian-iftikharuddin-the-stranger-in-the-house/ [accessed March 31, 2019]. ${ }^{23}$ Others were Zamindar, Nawa-i-Waqt and Civil and Military Gazette, all located in Lahore. See http://www.pressreference.com/No-Sa/Pakistan.html [accessed July 5, 2019]. 
${ }^{24}$ Kamran Asdar Ali, Surkh Salam: Communist Politics and Class Activism in Pakistan 1947-1972 (Karachi: OUP, 2015), p. 177.

${ }^{25}$ For the period after 1959, see Usmani, "Print Culture and Left-wing Radicalism in Lahore, Pakistan", pp. 201-46.

${ }^{26}$ Other beings Mazhar Ali Khan and Ahmad Ali Khan. See Usmani, "Print Culture and Left-wing Radicalism in Lahore, Pakistan", pp. 80-5.

${ }^{27}$ Asdar Ali, Surkh Salam, p. 177.

${ }^{28}$ Saadia Toor, The State of Islam: Culture and Cold War Politics in Pakistan (Oxford: OUP, 2011), p. 4.

${ }^{29}$ Yasmeen Hameed (ed.), Daybreak: Writings on Faiz (Karachi: OUP, 2013).

${ }^{30}$ https://www.dawn.com/news/606441 and http://www.faizcentenary.org/articles_by_faiz.htm [accessed January 25, 2019] and Sheema Majeed (ed.), Culture and Identity: Selected English Writings of Faiz and Coming Back Home: Selected Articles, Editorials and Interviews of Faiz Ahmed Faiz (Karachi: OUP, 2006, 2008).

${ }^{31}$ https://www.dawn.com/news/606752 [accessed January 25, 2019].

${ }^{32}$ Apart from Usmani, see Talat Ahmed, "Writers and Generals: intellectuals and the first Pakistan coup", Indian Economic and Social History Review, 45: 1 (2008), pp. 117-51 and Literature and Politics in the Age of Nationalism: The Progressive Episode in South Asia, 1932-56 (New Delhi: Routledge, 2009).

${ }^{33}$ Tai Yong Tan and Gyanesh Kudaisya, The Aftermath of Partition in South Asia (London: Routledge, 2000), pp. 125-41, 204-20.

${ }^{34}$ Pallavi Raghavan, "The Making of the India-Pakistan Dynamic: Nehru, Liaquat, and the No War Pact correspondence of 1950", Modern Asian Studies, 50: 5 (September 2016), pp. 1645-78.

${ }^{35}$ Usmani, "Print Culture and Left-wing Radicalism in Lahore, Pakistan", pp. 160-1. Also, see Daniel Haines, Rivers Divided: Indus Basin Waters in the Making of India and Pakistan (Oxford: OUP, 2017).

${ }^{36}$ Among which are included advertising, cinema and sports, which are not being covered in this article. On the former, see Kamran Siddiqui and Aisha Kamran, "History of Advertising in Pakistan”, Journal of Marketing Management and Consumer Behaviour, 1: 2 (2016), pp. 11-21. On cinema across Partition, see the writings of Dr. Salma Siddique and on sporting ties in its aftermath, see those of Dr. Boria Majumdar.

${ }^{37}$ Usmani, "Print Culture and Left-wing Radicalism in Lahore, Pakistan”, p. 91.

${ }^{38}$ See Rita Gairola Khanduri, Caricaturing Culture in India: Cartoons and History in the Modern World (Cambridge: CUP, 2014), pp. 93-118. 
${ }^{39}$ Usmani, "Print Culture and Left-wing Radicalism in Lahore, Pakistan", p. 5.

${ }^{40}$ Ibid., p. 72, p. 241.

${ }^{41}$ See http://www.pressreference.com/No-Sa/Pakistan.html [accessed July 5, 2019]. The exception alluded to here was Daily Imroze. See Usmani, “Print Culture and Left-wing Radicalism in Lahore, Pakistan”, p. 111.

${ }^{42}$ Usmani, "Print Culture and Left-wing Radicalism in Lahore, Pakistan", pp. 242-3.

${ }^{43}$ Ibid. pp. 82-3.

${ }^{44}$ Sheema Majeed, Coming Back Home (Karachi: OUP, 2008), p. vii.

${ }^{45}$ Usmani, "Print Culture and Left-wing Radicalism in Lahore, Pakistan", p. 135, 140

46 “Congress Standing on Verge of Precipice”, Thursday, 14 September 1950 (p. 2), Pakistan Times [hereafter PT].

${ }^{47}$ Myron Weiner, Party Politics in India: The Development of a Multi-Party System (Princeton: PUP, 1957), p. 70.

${ }^{48}$ Michael Brecher, Nehru: A Political Biography (Oxford: OUP, 1959), p. 397.

${ }^{49}$ Judith Brown, Nehru: A Political Life (New Haven: YUP, 2003), p. 194.

${ }^{50}$ Weiner, Party Politics in India, p. 70 and Benjamin Zachariah, Nehru (London: Routledge, 2004), pp. 180-2.

${ }^{51}$ Weiner, Party Politics in India, pp. 71-2.

${ }^{52}$ William Gould, Hindu Nationalism and the Language of Politics in Late Colonial India (Cambridge: CUP, 2004)

${ }^{53}$ Brown, Nehru, p. 194 and Brecher, Nehru, p. 166.

${ }^{54}$ Brown, Nehru, p. 194 and Zachariah, Nehru, p. 184.

${ }^{55}$ Weiner, Party Politics in India, pp. 71-2.

${ }^{56}$ Brown, Nehru, p. 194.

${ }^{57}$ Khaliquzzaman (1889-1973) went on to become the Governor of East Pakistan (1953-54) and thereafter

Pakistan's Ambassador to Indonesia and Philippines. See his memoir, Pathway to Pakistan (1961).

${ }^{58}$ Tuesday, March 15, 1949, Majeed, Coming Back Home, p. 17.

59 “Tandon’s Triumph”, Tuesday, September 5, 1950 (editorial, p. 4), PT.

${ }^{60}$ Zachariah, Nehru, p. 58 and Weiner, Party Politics in India, p. 83.

61 "Congress Standing on Verge of Precipice", Thursday, September 14, 1950 (p. 2), PT.

${ }^{62}$ Brown, Nehru, p. 195.

63 “Congress Policy”, Thursday, September 14, 1950 (editorial, p. 4), PT.

64 “Good start at Nasik", Wednesday, September 20, 1950 (editorial, p. 4), PT. 
65 “Tandon's Address", Friday, September 22, 1950 (editorial, p. 4), PT.

66 “Nasik session fails to give clear lead to people", Wednesday, September 27, 1950 (p. 3), PT.

67 "Nehru not to join Congress Executive", Thursday, October 12, 1950 (p. 1), PT.

68 "Indian Muslim Opinion", Tuesday, October 17, 1950 (editorial, p. 4), PT.

69 “Congress Trends”, Wednesday, October 18, 1950 (editorial, p. 4), PT.

70 “Congress affairs”, Sunday, November 5, 1950 (editorial, p. 4), PT.

71 “Major break in Congress Party expected”, Wednesday, December 13, 1950 (p. 1), PT.

${ }^{72}$ Brown, Nehru, p. 195.

${ }^{73}$ Weiner, Party Politics in India, pp. 73-8.

${ }^{74}$ See Rakesh Ankit, 'Jayaprakash Narayan, Indian National Congress and Party Politics', Studies in Indian Politics, 3: 2 (2015), pp. 149-63.

${ }^{75}$ See JS Grewal, Master Tara Singh in Indian History: Colonialism, Nationalism and the Politics of Sikh Identity (Delhi: OUP, 2017)

76 “Dr. Rajendra Prasad 66 years old”, "Congress has failed to fulfil pledges: JP Narain” and "Nationalist-Akali Parties Tussle: Sikh politics in E. Punjab”, Tuesday, December 5, 1950 (p. 2), PT.

77 “Sardar Vallabhbhai Patel dead”, Saturday, December 16, 1950 (p. 1), PT.

${ }^{78}$ Monday, February 2, 1948, Majeed, Coming Back Home, p. 56.

79 “Sardar Patel”, Saturday, December 16, 1950 (editorial, p. 4), PT.

${ }^{80}$ Weiner, Party Politics in India, p. 83.

${ }^{81}$ Brown, Nehru, p. 195.

82 “Congress Party has betrayed the country: JP Narain”, Tuesday, December 19, 1950 (p. 5), PT.

${ }^{83}$ Rajni Kothari, “The Congress 'System’ in India”, Asian Survey, 4: 12 (Dec. 1964), pp. 1161-73.

84 “Tandon's Triumph”, Tuesday, September 5, 1950 (editorial, p. 4), PT.

${ }^{85}$ See Pallavi Raghavan, 'The Finality of Partition: Bilateral Relations between India and Pakistan, 1947-1957'

(Ph.D. dissertation, Cambridge, 2012), chapter 3, 'Trade and Financial Relations between India and Pakistan', pp. 112-46.

86 "Pakistan at Par", 15 November 1949, The Economist; quoted in Raghavan, “The Finality of Partition", p. 130.

87 “Rupee Controversy”, Saturday, September 16, 1950 (editorial, p. 4), PT. 
${ }^{88}$ See Catherine R. Schenk, Britain and the Sterling Area: From Devaluation to convertibility in the 1950s (London: Routledge, 1994).

89 “Currency Devaluation and Pakistan-I”, Friday, September 29, 1950 (p. 4), PT.

${ }^{90}$ See Ayesha Jalal, The State of Martial Rule: The Origins of Pakistan's Political Economy of Defence (Cambridge: CUP, 1990).

91 “Pakistan Economy in 1950", Saturday, February 3, 1951 (p. 135), The Economic Weekly.

92 "Effect of devaluation on prices of Pakistani raw materials - decline in India's foreign trade", Sunday, October 1, 1950 (p. 4), $P T$.

93 “Talks likely for new Indo-Pakistan trade pact", Tuesday, October 3, 1950 (p. 1) and "India accepts the principle of 'no war'”, Friday, October 13, 1950 (p. 1), PT.

${ }^{94}$ Thursday, October 12 and Friday, October 13, 1950 (both p. 1), PT.

${ }^{95}$ See Tan and Kudaisya, The Aftermath of Partition in South Asia.

96 "General Elections postponed in India”, Wednesday, November 15, 1950 (p. 1), PT. Sunday, November 27, 1949, Majeed, Coming Back Home, p. 35.

97 “Indian elections", Thursday, November 16, 1950 (editorial, p. 4), PT.

${ }^{98}$ Friday, November 17, 1950 (p. 7), PT.

99 "Munshi prescribes faith as panacea for India's food shortage", Saturday, November 18, 1950 (last page), PT.

${ }^{100}$ Quoted in Benjamin Siegel, Hungry Nation: Food, Famine and the Making of Modern India (Cambridge: CUP, 2018), p. 64.

${ }^{101}$ See Taylor Sherman, "From 'Grow More Food' to 'Miss a Meal': Hunger, Development and the Limits of PostColonial Nationalism in India, 1947-1957”, South Asia: Journal of South Asian Studies, 36: 4 (2013), pp. 571-88.

102 “India’s Troubles", Saturday, November 18, 1950 (p. 4), PT.

103 “Joint Indo-Pakistan Defence", Saturday, November 18, 1950 (p. 4), PT.

104 “Rationing collapses in Bombay’s rural areas”, Friday, December 8, 1950 (p. 9), PT.

${ }^{105}$ See Siegel, Hungry Nation.

106 "India facing mass starvation without imported foodstuffs", Thursday, December 14, 1950 (p. 7), PT.

107 “India to abolish rural rationing", Thursday, December 14, 1950 (last page), PT.

108 “India wants to buy 2 m tons of US foodgrains", Tuesday, December 19, 1950 (p. 5), PT. 
109 “Food for India”, Sunday, January 7, 1951 (editorial, p. 4), PT.

110 “Shortage of raw material in India”, Monday, January 8, 1951 (p. 3), PT.

111 "India to slash defence expenditure", Saturday, January 13, 1951 (p. 1), PT.

112 "Increased railway fares in India likely", Saturday, January 13, 1951 (last page), PT.

113 “Bombay facing 25\% food cut”, Saturday, January 13, 1951 (last page), PT.

${ }^{114}$ Wednesday, January 17, 1951 (front page), $P T$.

115 “Indo-Pakistan Trade", Thursday, January 18, 1951 (editorial, p. 4), PT.

116 “Indo-Pakistan trade figures”, Sunday, January 21, 1951 (p. 11), PT.

${ }^{117}$ See David Engerman, The Price of Aid: The Economic Cold War in India (Massachusetts: HUP, 2018).

118 “Food for India”, Saturday, January 27, 1951 ('Between the Lines', p. 4), PT.

119 “Indian textile magnates threaten mill closure”, Tuesday, February 6, 1951 (p. 1), PT.

${ }^{120}$ Raghavan, “The Finality of Partition”, pp. 129-33.

121 “Trade deadlock”, Tuesday, February 13, 1951 (editorial, p. 4), PT.

${ }^{122}$ Usmani, "Print Culture and Left-wing Radicalism in Lahore, Pakistan”, p. 142. Wednesday, March 23, 1949, Majeed, Coming Back Home, p. 23.

123 “Pakistan Economy in 1950”, Saturday, February 3, 1951 (p. 135), The Economic Weekly; for more on interdominion trade see Raghavan, “The Finality of Partition”, pp. 133-45.

124 “Gandhiji’s birthday celebrations in Lahore”, Tuesday, October 3, 1950 (p. 3), PT.

125 See CM Naim, “The Maulana who loved Krishna”, Outlook (12 January 2012), https://www.outlookindia.com/website/story/the-maulana-who-loved-krishna/279545 [accessed March 31, 2019 ].

126 “Maulana Hasrat Mohani arrives in Lahore”, Wednesday, October 18, 1950 (p. 3), PT.

127 "New life \& new vistas for two hundred million", Wednesday, November 8, 1950 (p. 4), PT.

128 Thursday, November 9, 1950, p. 4), PT.

129 “The poet of peace”, Sunday, November 12, 1950, PT.

${ }^{130}$ Majeed, Coming Back Home, p. xi, pp. 43-5, 49-52.

131 “Liaquat elected League President”, Monday, October 9, 1950 (p. 1), PT.

132 “Mandal resigns from Pakistan Cabinet”, Monday, October 9, 1950 (p. 1), PT.

133 “Mandal's Diatribe”, Wednesday, October 11, 1950 (p. 4), PT. 
${ }^{134}$ See Dwaipayan Sen, The Decline of the Caste Question: Jogendranath Mandal and the Defeat of Dalit Politics in Bengal (Cambridge: CUP, 2018).

135 "Mandal has been inspired by Pakistan enemies: Lala Kotu Ram", "Mandal has let down minorities in Pakistan: Chaudhuri Tekka Ram" and “Mandal jeopardised minorities' interest: Mr. CW Tresler”, Friday, October 13, 1950 (p. 2), $P T$.

${ }^{136}$ Usmani, "Print Culture and Left-wing Radicalism in Lahore, Pakistan", p. 93.

${ }^{137}$ See T.R. Sharma, Communism in India: The Politics of Fragmentation (New Delhi: Sterling, 1984).

${ }^{138}$ See Javeed Alam, "State and the Making of Communist Politics in India, 1947-57”, Economic and Political Weekly, 26: 45 (November 9, 1991), pp. 2573-83.

${ }^{139}$ Tuesday, April 13, 1948, Tuesday, October 11, 1949 and Friday, October 14, 1949, Majeed, Coming Back Home, p. 3,26 and 30.

${ }^{140}$ See Bipan Chandra, 'PC Joshi: A Political Journey’, Mainstream Weekly, XLVI: 1 (December 25, 2007), https://www.mainstreamweekly.net/article503.html [accessed on March 30, 2019]

${ }^{141}$ See Ammar Ali Jan, “A Study in the Formation of Communist Thought in India, 1919-1951” (Ph.D. dissertation, Cambridge, 2018), chapter 6, "The Postcolonial Condition: Ranadive and the Search for Authenticity", pp. 121-46.

142 “Indian Communist Party reverses all decisions of expulsion \& suspension”, Wednesday, December 27, 1950 (p. 9), $P T$.

${ }^{143}$ See B. Uma Devi, Arrest, Detention and Criminal Justice System: A Study in the Context of the Constitution of India (Delhi: OUP, 2012).

144 “865 Communists detenues released in West Bengal”, Sunday, January 7, 1951 (p. 1), PT.

145 “First Communist rally in Calcutta after three years", Tuesday, January 16, 1951 (last page), PT.

${ }^{146}$ See John Roosa, "Passive revolution meets peasant revolution: Indian nationalism and the Telangana revolt", The Journal of Peasant Studies, 28: 4 (2008), pp. 57-94.

${ }^{147}$ See Rohit De, “The Flying QC: The postcolonial career of DN Pritt and the jurisprudence of decolonisation" (under review), https://history.yale.edu/people/rohit-de [accessed March 12, 2019].

148 "Plea for justice for Telangana Kisans”, Saturday, February 10, 1951 (last page), PT. 
${ }^{149}$ See Arudra Burra, "Freedom of Speech in the Early Constitution: A Study of the Constitution (First Amendment) Bill” in Udit Bhatia (ed) The Indian Constituent Assembly: Deliberations on Democracy (London: Routledge, 2017).

150 “Amendments to Indian constitution sought”, Wednesday, February 10, 1951 (last page), PT.

${ }^{151}$ See William Richter, "Princes in Indian Politics", Economic and Political Weekly, 6: 9 (February 27, 1971), pp. $535-42$.

152 "We Demand", Tuesday, January 25, 1949 and "Land and the Tiller", Sunday, March 13, 1949, Majeed, Coming Back Home, p. 10, 14.

153 “India's Princes", Wednesday, January 10, 1951 (p. 4), PT.

${ }^{154}$ See Peter Reeves, “The Congress and the abolition of Zamindari in Uttar Pradesh”, South Asia: Journal of South Asian Studies, 8: 1-2 (1985), pp. 154-67.

155 “Abolition of Zamindari”, Thursday, January 18, 1951 (page number unclear), PT.

${ }^{156}$ Usmani, "Print Culture and Left-wing Radicalism in Lahore, Pakistan”, p. 97.

157 “UP Land reform”, Thursday, January 18, 1951 (editorial, p. 4), PT.

158 “Sugar Industry in UP Paralysed”, Sunday, January 21, 1951 (p. 1), PT.

159 “Birla wants to set up textile mill in NWFP”, Sunday, January 21, 1951 (p. 11), PT.

160 “Indian capital in Pakistan”, Thursday, January 25, 1951 (editorial, p. 4), PT.

161 “Minorities must be assured of honourable existence: Dr. Prasad's broadcast on India Republic's first anniversary”, Friday, January 26, 1951 (last page), $P T$.

162 “Aruna Asaf Ali quits Socialist Party”, Tuesday, February 6, 1951 (p. 5), PT.

163 “Indian logic", Sunday, October 29, 1950 (p. 4), PT.

${ }^{164}$ Another example was Indonesia. See Usmani, "Print Culture and Left-wing Radicalism in Lahore, Pakistan", p. 91.

${ }^{165}$ Parshotam Mehra, The McMahon Line and After: A Study of the Triangular Contest on India's North-Eastern Frontier between Britain, China and Tibet, 1904-47 (Delhi: Macmillan, 1974).

166 “Liberation forces 100 miles from Lhasa", Sunday, November 5, 1950 (p. 1), PT.

167 “Tibet”, Sunday, November 5, 1950 (p. 4), PT. 
${ }^{168}$ See Amit Das Gupta and Lorenz Luthi (eds.), The Sino-Indian War of 1962: New Perspectives (Delhi: Routledge, 2016).

169 "King of Nepal flees Palace: Asylum sought in Indian Embassy", Wednesday, November 8, 1950, PT.

${ }^{170}$ Prashant Jha, Battles of the New Republic: A Contemporary History of Nepal (London: Hurst, 2014), p. 9.

${ }^{171}$ John Whelpton, A History of Nepal (Cambridge: CUP, 2005), pp. 61-4.

${ }^{172}$ Ibid. p. 67.

${ }^{173}$ Ibid. p. 68.

${ }^{174}$ Jha, Battles of the New Republic, p. 10.

${ }^{175}$ Ibid.

${ }^{176}$ Whelpton, A History of Nepal, p. 69.

${ }^{177}$ Ibid. p. 70.

178 “Nepal and India”, Friday, November 10, 1950 (p. 4), PT.

${ }^{179}$ Whelpton, A History of Nepal, pp. 70-1.

180 "Congress volunteers occupy second biggest town in Nepal”, Sunday, November 12, 1950 (p. 1), PT.

181 "Happenings in Nepal”, Wednesday, November 15, 1950 (p. 4), PT.

182 “Whither Nepal?”, Saturday, November 18, 1950 ('Between the Lines', p. 4), PT.

${ }^{183}$ Majeed, Coming Back Home, pp. viii-xi.

184 “India wants to be sure of Nepal", Sunday, November 19, 1950 (last page), PT.

185 "Nepali Congress rebellion collapses", Tuesday, November 21, 1950 (p. 1), PT.

186 "Nepal and India", Thursday, November 23, 1950 (p. 4), PT.

187 “Nepalese Scene”, Friday, December 1, 1950 (p. 4), PT.

188 “What is happening in Nepal?", Sunday, December 3, 1950 (p. 8), PT.

${ }^{189}$ Whelpton, A History of Nepal, p. 71.

${ }^{190}$ Ibid.

191 “India over Nepal”, Friday, January 5, 1951 (editorial, p. 4), PT.

192 “Nepalese scene”, Friday, January 12, 1951 (editorial, p. 4), PT.

${ }^{193}$ S. Amatya, Rana Rule in Nepal (Kathmandu: Nirala, 2004), p. 191.

${ }^{194}$ Whelpton, A History of Nepal, p. 86. 
195 Jha, Battles of the New Republic, p. 10.

196 Usmani, "Print Culture and Left-wing Radicalism in Lahore, Pakistan”, p. 142.

${ }^{197}$ See Estelle Dryland, "Faiz Ahmed Faiz and the Rawalpindi Conspiracy Case", Journal of South Asian Literature, 27: 2 (Summer, Fall 1992), pp. 175-85, Hasan Zaheer, The Times and Trial of the Rawalpindi Conspiracy 1951: The First Coup Attempt in Pakistan (Lahore: Sang-e-Meel, 2007), Chapters 3-5 and epilogue and "Faiz Ahmed Faiz: About myself and what I have been up to", Think India Quarterly, 14: I (January - March 2011), pp. 59-71.

198 Asdar Ali, Surkh Salam, pp. 196-7.

${ }^{199}$ Majeed, Coming Back Home, p. viii.

200 "Charge of Conspiracy”, Saturday, March 10, 1951; see Pakistan: The First Twelve Years: The Pakistan Times Editorials of Mazhar Ali Khan (Karachi, Oxford University Press, 1996), pp. 265-6.

${ }^{201}$ Asdar Ali, Surkh Salam, p. 197.

202 Toor, The State of Islam, p. 87.

${ }^{203}$ Ibid.

${ }^{204}$ Usmani, "Print Culture and Left-wing Radicalism in Lahore, Pakistan”, p. 38.

${ }^{205}$ Walter Lippmann, Public Opinion (New York: Free Press, 1997), p. 18.

${ }^{206}$ See Rochelle Pinto, Between Empires: Print and Politics in Goa (Delhi: OUP, 2007).

${ }^{207}$ See Amelia Bonea, The News of Empire: Telegraphy, Journalism, and the Politics of Reporting in Colonial India, c. 1830-1900 (Delhi: OUP, 2016).

${ }^{208}$ See Michael Mann, Wiring the Nation: Telecommunication, Newspaper-Reportage, and Nation Building in British India, 1850-1930 (Delhi: OUP, 2016).

${ }^{209}$ Usmani, "Print Culture and Left-wing Radicalism in Lahore, Pakistan”, p. 142. 